\title{
Moral Outrage, Intolerance of Uncertainty and Relational Interdependence during the COVID-19 Pandemic: A Social Psychology Research
}

\author{
Lokman Koçak ${ }^{1}$
}

\begin{abstract}
This study focuses on the mediating role of relational interdependence in the relationship between moral outrage and intolerance of uncertainty during the COVID-19 pandemic. The Moral Outrage Scale, Intolerance of Uncertainty Scale and Relational Interdependence Scale were administered to a sample of 821 adults (66\% females and 34\% males). The participants were aged between 18 and 75, with an average age of 34.05 ( $\mathrm{SD}=9.81$ ). The data was analysed with correlation analysis and regression-based mediation analysis to investigate the relationship between relational interdependence, moral outrage and intolerance of uncertainty. Furthermore, a bootstrap method was used to examine the direct and indirect effects in the mediation model. The findings showed that relational interdependence has a mediating effect on the relationship between moral outrage and intolerance of uncertainty. The results obtained are discussed in the context of the relevant literature.
\end{abstract}

Keywords: Social Psychology, COVID-19, Moral Outrage, Intolerance of Uncertainty, Relational Interdependence

\section{Introduction}

In order for the feelings, thoughts and behaviors of a human being to be understood correctly, they should be examined together with the social environment that the individual inhabits. Social psychology examines the behavior of an individual or individuals in society; at the same time, it tries to understand how those feelings, thoughts, beliefs and attitudes are affected by the social environment (Kağıtçıbaşı \& Cemalcılar, 2014). Social psychology; it is expressed as a scientific discipline that scientifically examines the social and cognitive processes that affect individuals' perception, impact and relationship with others (Smith \& Mackie, 2007). The word "social" in social psychology can be used to mean different things, such as "interactions between people", "society or culture", "problems that concern many people" and "involving more than one person" (McGarty \& Haslam, 1997). In this context, it can be said that the COVID-19 pandemic -which affects the cognitive, emotional and behavioral aspects of the whole world's societies- redesigns the interactions between people and concerns everyone. Therefore, it is an important social issue and should be examined from the perspective of social psychology.

The COVID-19 pandemic, which started in Wuhan, China in December 2019 and spread to other parts of the world, has emerged as a global health threat (Cao et al., 2020; Wang et al., 2020). The World Health Organization (WHO) announced that the spread of this new coronavirus, which it called COVID-19, can

\footnotetext{
1 Sakarya University, Institute of Education Sciences, Turkey, lokmankocak@sakarya.edu.tr, ORCID: https://orcid.org/0000-0002-5247-0974
} 
be averted by the implementation of a robust system for early detection, isolation, rapid treatment and contact monitoring (Sohrabi et al., 2020), and declared it a global epidemic threatening public health in the international context on January 30, 2020 (Sun et al., 2020). The COVID-19 infection -which has symptoms such as fever, cough and shortness of breath- was first detected in Turkey on March 11 (Ministry of Health, 2020). The virus has been the subject of many studies in various countries across the world. Reports have been published on the psychological effects of the COVID-19 pandemic on the general public (Özdin \& Bayrak Özdin, 2020), patients (Bo et al., 2020), medical staff (Asmundson \& Taylor, 2020), children (Teo \& Griffiths, 2020), students (Cao et al., 2020) and the elderly (Meng et al., 2020).

The COVID-19 pandemic has been the cause of fear and anxiety (Ahorsu et al., 2020). Although vaccinations have started in many countries around the world, the number of people who think COVID19 is a conspiracy and who have a negative attitude to the vaccine is quite high (Geniş et al., 2020). This situation has increased the fears and anxieties about the epidemic and uncertainty about the future. Uncertainty is defined as a concept that can have negative effects on human psychology (Sarıçam et al., 2014). It causes feelings of anxiety and fear in people who want reassurance about their future (Sarı \& Dağ, 2009). During the pandemic process, anxiety, fear and uncertainty have interacted in multiple ways. The tendency to exhibit negative reactions to uncertain events and situations -emotionally, cognitively and behaviorally- manifests itself as intolerance (Buhr \& Dugas, 2002).

Intolerance of uncertainty is defined as a tendency to react negatively (emotionally, cognitively and behaviorally) to uncertain events and situations (Buhr \& Dugas, 2002). Also, intolerance of uncertainty has been described as the tendency to perceive uncertain situations as a source of danger (Grenier et al., 2005). In the literature, uncertainty is explained as doubts about the future (Sarıçam et al., 2014) and the cognitive situation arising from an inability to make sense of the events experienced (Crigger, 1996). Uncertainty places severe stress on the individual (Bailey et al., 2009). In the studies conducted, intolerance of uncertainty has been positively related to pathological anxiety (Holaway et al., 2006), anxiety disorder (Belge, 2019), obsessive-compulsive disorder (Özkan, 2019), and self-inhibition and perfectionism (Güvenç, 2019). Resilience (Saatçı, 2020) and cognitive flexibility (Güvenç, 2019) were found to be negatively related to intolerance of uncertainty.

The COVID-19 pandemic has brought many restrictions in daily life, and strict measures have been taken, both in particular provinces and countrywide, to prevent the spread of the epidemic. These measures have included a transition to an online education system, the restriction of intercity travel, curfews for citizens in some age groups, the closure of social venues and the declaration of a nationwide curfew for certain periods (BBC News, 2020). At the same time, the country's administrators have asked citizens to cooperate by quarantining themselves voluntarily and staying at home as much as possible. In the COVID-19 pandemic, people's individual compliance or non-compliance with these rules affects other people. In this case, it is natural for those people who follow the rules to react against those who do not obey them. Moral outrage is increasing as the individual efforts of people are insufficient to protect them from the ravages of COVID-19 infection (Rushton \& Thompson, 2020).

Moral outrage is defined as an emotion that is caused by the violation of moral standards, such as fairness and justice (Hoffman, 2001; Montada \& Schneider, 1989). When moral identity and integrity are compromised, moral outrage is expressed in justified anger, disgust or disappointment directed at 
others who violate ethical values and standards (Goodenough, 1997). When moral outrage is activated, the nervous system can become locked into a state of overstimulation, and the stimulation of a number of stress hormones can put the individual in a depressed, exhausted, apathetic or anxious mood (Rushton, 2013). Indicating injustice towards others and addressing their well-being can be explained by the fact that moral outrage is based on altruism (Goodenough, 1997). Moral outrage can be a source of inspiration and insight for compassionate action and principled understanding. It helps the body to be aware when its safety, integrity or well-being is threatened. This provides an opportunity to explore the moral limits of courage, patience and responsibility (Thomas et al., 2009). People are sensitive to moral outrage, but few are capable of using its power constructively. Undetermined moral outrage can increase differences, exacerbate discrimination and weaken prosocial behavior (Rushton \& Thompson, 2020). Moral outrage is covered by various socio-psychological concepts and topics, such as system justification (Wakslak et al., 2007), social dominance (Kugler et al., 2010), right-wing authoritarianism (Tan et al., 2016), sexist stereotypes (Çelik Ok, 2019a), accepting rape myths (Chapleau \& Oswald, 2014), persuasion (Lee, 2010), social actions (Pagano, 2007) and the gender system (Quasney, 2011).

Since the emergence of COVID-19, a number of recommendations have been made by the authorities to prevent the virus from spreading to more people. Restricting social contact is one of the most frequently and strongly emphasized suggestions. As a result of this recommendation, which is also expressed in the form of maintaining social distance, people could not meet the need for socialization sufficiently and experienced many problems in issues such as self-esteem, belonging and control in their social relationships (Brooks et al., 2020; Sher, 2020). It is to be expected that problems in social relations affect close relationships negatively. In addition, due to COVID-19, conducting social relationships online and confining face-to-face interactions to a very narrow and limited space can also harm close relationships. In this case, the concept of relational interdependence, which has an important connection with close relationships, is raised.

Although the concept of relational interdependence is based on the assumption of the individual and collective self (Markus \& Kitayama, 1991), it focuses on the concept of relationships between me and the group. In other words, the relational interdependence moves away from the ambiguous and wideranging stance of the group category and treats the person within the framework of close relationships (Cross et al., 2002). Relational interdependence is defined as the level of identifying oneself with close relationships (Cross et al., 2000). People with a high level of identification with their closer surroundings are thought to have strong relational interdependence. It is stated that people may have independent attitudes towards individual, collective and relational interdependence, and these people may want to protect and develop their relational interdependence by trying to be with their close surroundings (Cross et al., 2002). Therefore, people with high relational interdependence are thought to have different cognitive, emotional and motivational processes compared to other self types (Cross \& Madson, 1997). The concept of relational interdependence is discussed under topics such as the learning levels of nursing students (Sweet \& Broadbent, 2017), self-construal (Ercan, 2013), working life (Billett, 2006) and learning in working life (Billett, 2008).

\section{The Mediating Role of Relational Interdependence}

When the COVID-19 pandemic occurred, governments around the world resorted to numerous measures -such as the wearing of masks, maintaining social distancing, staying at home- to try to slow 
the spread of the virus. Although many people found it easy to adopt these measures, the number of people who did not follow the rules was substantial. News reports documented some people flocking to beaches and parks, hanging out with friends or holding house parties (Cummins, 2020; Ryan, 2020). These violations were met with harsh condemnation and moral outrage in the press and social media (Coffey, 2020; Helweg-Larsen, 2020; O'Sullivan \& Patino, 2020). When people are exposed to numerous restrictions and bans due to an epidemic, they might be expected to feel moral outrage towards those who do not obey the same rules and measures. In this extraordinary environment, where one person's violation of the rules can have a negative effect on many people and may even be life-threatening, the level of moral outrage will naturally increase. Moral outrage, which can also be a source of motivation in important social events (Montada, 1992), can be expected to manifest itself as disappointment and aggression during the period of an epidemic (Lodewijkx et al., 2008). In addition, more than a year has passed since the first case was seen, but people still do not have a date for the end of the epidemic, and the emergence of new waves in the course of the epidemic may cause an increase in the intolerance of uncertainty. In this difficult period, some people's failure to obey the rules can increase the moral outrage of others and also exacerbate their intolerance of uncertainty.

In one study, it is stated that there is a relationship between moral outrage and system justification and that, as system justification increases, so moral outrage decreases (Wakslak et al., 2007). System justification is defined as a type of adaptation that reduces the negative feelings of individuals -such as anxiety, guilt or uncertainty- regardless of their social position (Jost \& Hunyady, 2002). People are comforted psychologically when they adopt the existing political, social or economic regulations (Jost, 2011). Similarly, It can be thought that the rule violations by people with identification will not increase moral outrage. In another study, a negative relationship was found to exist between moral outrage on the one hand and right-wing authoritarianism and an orientation towards social dominance on the other, and it was found that moral outrage decreased as right-wing authoritarianism and social dominance increased (Tan et al., 2016). Right-wing authoritarianism describes the psychological submission that an individual displays towards the people he/she accepts as an authority in his/her life (Altemeyer, 1996). Orientation towards social dominance is defined as the desire of the groups in which the individual is located to have social dominance and superiority over other persons or groups. (Sidanius \& Pratto, 1999). This information indicates that people's moral outrage is significantly influenced by the other people or groups with whom they are closely related and their views. On the other hand, another study found that there was no relationship between moral outrage and self-esteem (Pagano, 2007). This finding suggests that moral outrage may be related to relational interdependence, which is based on close relationships rather than the individual self.

The insensitivity and uncertainties that have arisen during the COVID-19 pandemic can cause moral outrage to increase the intolerance of uncertainty. However, in the course of the epidemic, people may ignore the fact that those with whom they have close relationships and identify with do not follow some of the rules, or they may believe that it should already be like this. Therefore, it can be predicted that the power of moral outrage to affect intolerance of uncertainty will decrease with the effects of relational interdependence. When the literature is reviewed, during the COVID-19 pandemic period, intolerance of uncertainty (Bakioğlu et al., 2020; Duman, 2020; Kasapoğlu, 2020; Parlapani et al., 2020; Tull et al., 2020; Scharmer et al., 2020; Wheaton et al., 2020 ), moral outrage (Godshall, 2021; Neys et al., 2020; Davidson et al., 2020; Rushton \& Thompson, 2020) and relational interdependence (Graupmann \& 
Pfundmair, 2020) have all been the subject of studies. However, no studies have been found in which these concepts, which are thought to be related to each other, have actually been examined together. In this respect, the purpose of this study is to examine the mediating role of relational interdependence in the relationship between moral outrage and intolerance of uncertainty during the COVID-19 pandemic.

\section{Method}

In this study; survey method was used to examine the relationship between moral outrage, intolerance of uncertainty and relational interdependence. In these studies, where the relationships are examined in depth, it is aimed to describe the relationships between two or more variables and to determine the existence or degree of change (Karasar, 2014).

\section{Participants}

The study group consisted of a total of 821 adults, aged between 18 and 75 (Mean = 34.05, SD=9.81), 573 females $(66 \%)$ and 278 males (34\%). Education levels of the participants were determinded as $4.3 \%(N=$ $35)$ primary school, $2.4 \%(N=20)$ secondary school, $9.6 \%(N=79)$ high school, $7.2 \%(N=59)$ associate degree, $61.1 \%(N=502)$ undergraduate degree, and $15.3 \%(N=126)$ postgraduate degree. $65 \%$ of the participants $(\mathrm{N}=536)$ are married and $35 \%(N=285)$ are single. $12.1 \%(N=99)$ of the participants were diagnosed with COVID-19 $(+) ; 87.9 \%(N=722)$ of them were not diagnosed with $(+)$. Relatives of $71.4 \%$ $(N=586)$ of the participants were diagnosed with COVID-19 $(+)$, and any relative of $28.6 \%(N=235)$ was not diagnosed with COVID-19 (+).

\section{Instruments}

\section{Moral Outrage Scale}

The scale developed in German by Montada and Schneider (1989) and later adapted to English by Wakslak et al. (2007), it was adapted to Turkish culture by Çelik Ok (2019b). The scale, which consists of 10 items and one dimension in total, is a 9-point Likert type measurement tool. As a result of EFA, the 2nd item with a factor load below .30 was removed from the scale. It has been determined that the CFA results have a good level of compliance $(G F I=.95, A G F I=.90, C F I=.95$ ve $R M S E A=.08)$. As a result of the analysis, it was seen that the scale had a two-factor structure, unlike the original one. Considering the item contents, these factors were named as "emotional moral outrage" and "cognitive moral outrage". When the internal consistency level of the scale was examined, it was found that the Cronbach Alpha coefficient was .78 and .70, respectively. In its final form, it was stated that the scale consists of 9 items and two sub-dimensions (Çelik Ok, 2019b).

\section{Intolerance of Uncertainty Scale}

The scale was developed by Carleton et al. (2007) and it was adapted to Turkish culture by Sarıçam et al. (2014). As a result of CFA applied for the construct validity of the scale, it was seen that 12 items were collected in two dimensions (forward anxiety and preventive anxiety), consistent with the original form $\left(\chi^{2}=147.20, \mathrm{SD}=48, \mathrm{RMSEA}=.073, \mathrm{CFI}=.95, \mathrm{IFI}=.95, \mathrm{GFI}=.94\right.$, and SRMR $\left.=.046\right)$. The factor loads of the scale range between .55 and .87 . The internal consistency coefficient for the whole scale is $\alpha=.88 ; \alpha=$ .84 for forward anxiety and $\alpha=.77$ for the preventive anxiety sub-dimension. Test-retest correlation coefficient was found as .74; in addition, it was observed that the corrected item-total correlations of the 
scale ranged between .42 and .68. The scale, which is a Likert type measurement tool, is scored as (1) "not suitable for me", and (5) "completely suitable for me".

\section{Relational Interdependence Scale}

The scale developed Cross et al. (2000), it was adapted to Turkish culture by Öztürk et al. (2015). The scale, which consists of 11 items and one dimension in total, is a 7-point Likert type measurement tool. As a result of EFA, the 3rd item with a factor load below .30 (.19) was removed from the scale. It has been determined that the CFA results have a good level of compliance (GFI $=.87$, TLI $=.75, \mathrm{CFI}=.80$, and RMSEA = .10). As a result of the analysis, it was seen that the scale had a two-factor structure, unlike the original one. Considering the item contents, these factors were named as "identification" and "reflection". When the internal consistency level of the scale was examined, it was found that the Cronbach Alpha coefficient was .77 and .81, respectively. In its final form, it was stated that the scale consists of 10 items and two sub-dimensions (Öztürk et al., 2015).

\section{Data Analysis}

First, the distribution was examined in terms of normality, and the skewness and kurtosis values were reviewed to determine whether the data were suitable for normal distribution. The skewness values of the variables are in the range of .02 to -1.26 ; the kurtosis values are between .06 and 1.35 and the values are between -1.5 and +1.5 show that the data are at an acceptable level in terms of normality (Tabachnick \& Fidell, 2013). As a result of the correlation analysis, it is seen that there is a positive and significant relationship between intolerance of uncertainty and emotional moral outrage $(r=.18, p<.05)$ and identification $(r=.22, p<.05)$. In addition, a positive and significant relationship was found between emotional moral outrage with identification $(r=.28, p<.05)$ and reflection $(r=.13, p<.05)$. The correlation values obtained show that a mediation model can be established by identification, which is the subdimension of relational interdependence, and emotional moral outrage which is the sub-dimension of moral outrage. Findings regarding the assumptions of normality are shown in Table 1.

\section{Table 1}

Descriptive Statistics, Reliability and Correlations between Intolerance of Uncertainty with Moral Outrage and Relational Interdependence

\begin{tabular}{|c|c|c|c|c|c|c|c|c|c|}
\hline & \multicolumn{2}{|c|}{ Moral Outrage } & \multicolumn{2}{|c|}{$\begin{array}{l}\text { Reliatonal } \\
\text { Interdependence }\end{array}$} & \multicolumn{5}{|c|}{ Descriptive Statistics } \\
\hline & EMO & $\mathrm{CMO}$ & I & $\mathrm{R}$ & $\alpha$ & Mean & SD & Skewness & Kurtosis \\
\hline IU & $.18^{* * *}$ & .04 & $.22^{* * *}$ & -.00 & .86 & 37.68 & 8.30 & .02 & -.06 \\
\hline EMO & & $.30^{* * *}$ & $.28^{* * *}$ & $.13^{* * *}$ & .80 & 40.00 & 5.50 & -1.26 & 1.35 \\
\hline $\mathrm{CMO}$ & & & .05 & $.19^{* * *}$ & .75 & 26.92 & 6.84 & -.63 & .02 \\
\hline I & & & & $.48^{* * *}$ & .78 & 38.35 & 6.92 & -.55 & .13 \\
\hline $\mathrm{R}$ & & & & & .63 & 20.48 & 4.55 & -.42 & .03 \\
\hline
\end{tabular}

${ }^{*} p<.05,{ }^{* *} p<.01,{ }^{* * *} p<.001$ 
Abbreviations: IU: Intolerance of Uncertainty; EMO: Emotional Moral Outrage; CMO: Cognitive Moral Outrage; I: Identification; R: Reflection; $\alpha$ : Cronbach's Alpha; SD: Standart Deviation.

After the data set provided the assumptions of normality, the regression analysis assumptions were reviewed. In the findings obtained, Tolerance values of all variables are greater than .10 and VIF values are lower than 10, indicating the normality of the data set and no multi-connection problem in the data set (Pallant, 2007).

In the study, the mediation model of factors that predict intolerance of uncertainty was examined with Process macro, which was developed by Hayes (2013) and works as a plug-in in SPSS software. In this additional software, which uses 5000 resample method in regression analysis, path coefficients, standard errors, $\mathrm{t}$ and $\mathrm{p}$ values and bootstrap confidence intervals of all variables in a research model can be calculated. In this respect, it is suggested that the Process macro can be used for path analysis and that many regression equations can be easily modeled by researchers (Hayes, 2013). According to MacKinnon et al. (2002), it is an analysis method that mediation analysis is used to determine whether the relationship between the independent variable $(X)$ and the dependent variable $(Y)$ significantly decreases with the addition of a regression equation intermediary variable (M). The indirect effects of the relational interdependence, the mediator variable of this study, were interpreted using the bootstrap technique. Mediation is considered to be significant if there is no zero between the bootstrap lower (BootLLCI) and upper (BootULCI) values at 95\% confidence interval of the mediator variables, in other words, both values are below or above zero (Hayes, 2013; Zhao et al., 2010). Fully standardized impact size of the mediation effect $\left(\mathrm{K}^{2}\right)$ was interpreted by taking into account the values "low effect if close to .01", "medium effect if close to .09" and "high effect if close to .25" recommended by Preacher and Kelley (2011). Basic mediation analysis was performed using Model 4 in the process macro software. Emotional moral outrage is the independent variable of the research, identification is the mediator variable, and the intolerance of uncertainty is the dependent variable. Emotional moral outrage, which is the subdimension of moral outrage, was expressed as "moral outrage" and identification, which is the subdimension of the relational interdependence, was expressed as "relational interdependence" in terms of consistency with the literature. Information on the model to be tested is shown in Table 2.

Table 2

Model to Test

\begin{tabular}{llll}
\hline & Independent Variable & Mediator Variable & Dependent Variable \\
\hline Mediating Model & Moral Outrage & Relational Interdependence & Intolerance of Uncertainty \\
\hline
\end{tabular}

Findings

Whether moral outrage predicts intolerance of uncertainty through the relational interdependence during the COVID-19 pandemic was examined with Process macro developed by Hayes (2013). Mediation model is shown in Table 3. 


\section{Table 3}

The Mediating Role of Relational Interdependence in the Relationship between Moral Outrage and Intolerance of Uncertainty

$$
\text { Relational Interdependence Intolerance of Uncertainty }
$$

Model

$(\mathrm{M})$

$(\mathrm{Y})$

\begin{tabular}{lllllll} 
& $\beta$ & SE & $t$ & $\beta$ & SE & $t$ \\
\hline Moral Outrage $(\mathrm{X})$ & .36 & 04 & 8.56 & .19 & .05 & 3.69 \\
Relational Interdependence (M) & - & - & - & .21 & .04 & 5.18 \\
Constant & 23.93 & 1.70 & 14.07 & 21.39 & 2.29 & 9.31 \\
& $R^{2}=.08, F(1,819)=73.32, p<.01$ & $R^{2}=.06, F_{(2,818)}=28.07, p<.01$ \\
\hline Bootstrap Results for Indirect Effects & & & B & Boot & BootLLCI & BootULCI \\
\hline Indirect Effect Relational Interdependence & & .08 & .02 & .04 & .12
\end{tabular}

Table 3 includes the results of the regression analysis showing the effect of the relational interdependence $(\mathrm{M})$, which is the mediator variable between moral outrage $(X)$ and intolerance of uncertainty $(Y)$. In addition to that, it was determined that moral outrage positively predicted relational interdependence $(\beta=.36 ; t=8.56 ; p<.05)$ and intolerance of uncertainty $(\beta=.19 ; t=3.69 ; p<.05)$. On the other hand, it was determined that the relational interdependence also positively predicted intolerance of uncertainty $(\beta=.21 ; t=5.18 ; p<.05)$. In this context, the indirect effect of the relatioanal interdependence, the mediator variable, at 95\% confidence interval BootLLCIRI $=.04$; BootULCIRI $=.12$ is calculated. Since there is no zero between the bootstrap lower (BootLLCI) and upper (BootULCI) values at $95 \%$ confidence interval, the relational interdependence has a significant mediating role in this model. $K^{2} R l=.08$, which is the fully standardized effect size value of the mediation effect, shows that the mediating effect has a medium value. The diagram of the model is shown in Figure 1. 


\section{Figure 1}

The Mediating Role of the Relational Interdependence in the Relationship between Moral Outrage and Intolerance of Uncertainty

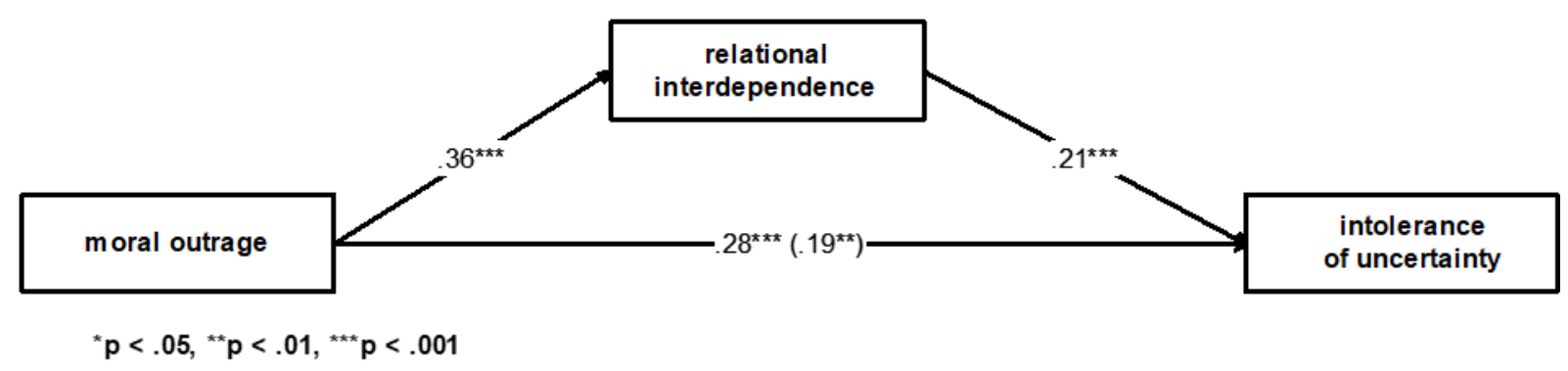

\section{Discussion}

This study tested whether relational interdependence had a mediating role in the relationship between moral outrage and intolerance of uncertainty during the COVID-19 pandemic, and it was found that relational interdependence had a partial mediating effect. When the literature was examined, no research was discovered in which this model was tested. In addition, none of the studies examined these variables together. However, it has been determined that in the COVID-19 pandemic, existing variables were investigated with different concepts. Studies have shown that there are positive relationships between intolerance of uncertainty and fear of COVID-19 (Duman, 2020), depression, anxiety and stress (Bakioğlu et al., 2020), eating disorders (Scharmer et al., 2020), obsessive-compulsive disorder (Wheaton et al., 2020), health anxiety (Tull et al., 2020) and loneliness (Parlapani et al., 2020). It was determined that there is a negative relationship between intolerance of uncertainty and spirituality and resilience (Kasapoğlu, 2020). These findings show that intolerance of uncertainty has been accompanied by many problems during the COVID-19 pandemic. The concept of moral outrage has been examined under the guise of "coping with moral distress" (Godshall, 2021), "social distancing" (Neys et al., 2020), "understanding moral outrage" (Davidson et al., 2020) and "moral outrage: promise or peril" (Rushton \& Thompson, 2020) during the COVID-19 pandemic. In these studies, it is emphasized that during the COVID-19 pandemic, especially when people do not comply with the suggested rules, intense moral outrage will be experienced and that this can cause serious problems. The concept of relational interdependence was examined together with social distance (Graupmann, 2020) and it was mentioned that social distance, which has frequently been emphasized during the COVID-19 pandemic, may harm relational interdependence.

People with high relational interdependence feel more self-confident when they are in familiar surroundings (Gabriel et al., 2007) and, when faced with a threat, they use these relationships more frequently (Chen \& Boucher, 2008). In this respect, it can be said that relational interdependence can mitigate the moral outrage that occurs when moral identity and integrity are endangered (Goodenough, 1997) and reduce the possible negative effects of moral outrage. In addition, the higher the relational interdependence, the more behaviors that support the relationship are displayed (Morry \& Kito, 2009). This positive effect of relational interdependence provides higher relationship satisfaction and const- 
ructive behaviors by strengthening the bond with others (Mattingly et al., 2011). It is stated that when moral anger is used as a reactive strategy, when a threat is felt against professional identities, values, beliefs or integrity, it acts as a glue that holds the group or society together by creating a sense of solidarity (Rushton, 2013). In this case, it can be said that, with this positive effect of relational interdependence, moral outrage can be experienced in a more balanced way and the resulting energy can be channeled into constructive behaviors. On the other hand, it is stated that people with high relational interdependence exhibit compromising behavior (Gelfand et al., 2006). In other words, the individual may adopt some of the behaviors of other individuals with whom he/she is in a close relationship, even if it is not suitable for him/her and exhibit the same behaviors himself/herself. It can be said of a person who feels moral outrage, if the rules of the COVID-19 pandemic are not followed, that his/her moral outrage will decrease when people with whom he/she has close relationships commit this violation, or when he/she behaves in the same way.

It is stated that the intentions and actions of individuals have complex social genes (Billet, 2006). In addition, it is stated that individuals fulfill their existing duties and social responsibilities with the contribution of relational interdependence (Ercan, 2013). In the COVID-19 pandemic, social duties and responsibilities have become more important than ever. In this case, it might be thought that people with strong relational interdependence will have no difficulty in complying with the rules of the epidemic and will reduce the possibility of any intolerance of uncertainty and moral outrage that may arise. On the other hand, it can be said that close interpersonal relations are dominant in Turkish culture and individuals are closely tied to their families, relatives and close neighbors. Traditional socialization processes emphasize commitment to family, close relationships and obedience, rather than independence and self-confidence (İmamoğlu, 2003). In cultures that have a collectivist structure such as Turkish culture, individuals define the concept of self as a commitment to others and prefer mutual dependence rather than independence in a relational sense (Mesquita, 2001; Triandis \& Suh, 2002). Based on this information, it can be said that relational interdependence is an important determinant in Turkish society. On the other hand, the rate of being affected by discrimination was found to be lower in collectivist cultures with stronger relational dependences (Pfundmair et al., 2015; Uskul \& Over, 2017). This finding indicates that relational interdependence can reduce the impact of discrimination in society, which is one of the main sources of moral outrage (Rushton \& Thompson, 2020).

The research results show that relational interdependence has played a mediating role in the relationship between moral outrage and intolerance of uncertainty during the COVID-19 pandemic. In line with this result, it can be said that relational interdependence will reduce the effect of moral outrage on the intolerance of uncertainty during the COVID-19 pandemic. Based on this information, some suggestions can be made: Extensive research can be conducted to identify other concepts that may be related to the relatioanal interdependence. In addition, examining the concept of relational interdependence with social psychology concepts such as persuasion, attitude change and compliance behavior which constitute social impact may be important in terms of discovering the influential power of relational interdependence. In the literature of social psychology, the concepts of moral outrage, intolerance of uncertainty and relational interdependence are discussed under different titles; however, it is striking that they have not been examined together. In this respect, examining the aforementioned concepts with different samples and contents could contribute to the social psychology literature. 
Obtaining the findings in the study from data collected through self-reporting scales might be a limitation, since it carries the risk of resource bias. The fact that the majority of people surveyed were graduates of university may have created a limitation in terms of the generalizability of the results. Another limitation is that the research was carried out with the survey method. While the results provide information about the direction and amount of the relationships dealt with in the research, they do not contain a cause effect relationship.

\section{References}

Ahorsu, D. K., Lin, C. Y., Imani, V., Saffari, M., Griffiths, M. D., \& Pakpour, A. H. (2020). The fear of COVID- 19 scale: Development and initial validation. International Journal of Mental Health and Addiction, 27, 1-9. https://doi.org/10.1007/s11469-020-00270-8

Altemeyer, B. (1996). The authoritarianism specter. Harvard University Press.

Asmundson, G. J., \& Taylor, S. (2020). How health anxiety influences responses to viral outbreaks like COVID-19: What all decision-makers, health authorities, and health care professionals need to $\begin{array}{lllll}\text { know. Journal of Anxiety Disorders, } & 102211 .\end{array}$ https://dx.doi.org/10.1016\%2Fj.janxdis.2020.102211

Bailey, D. E. Jr., Landerman, L., Barroso, J., Bixby, P., Mishel, M.H., Muir, A.J., \& Clipp, E. (2009). Uncertainty, symptoms, and quality of life in persons with chronic hepatitis C. Psychosomatics, 50, 138-146. https://doi.org/10.1176/appi.psy.50.2.138

Bakioğlu, F., Korkmaz, O., \& Ercan, H. (2020). Fear of COVID-19 and positivity: mediating role of intolerance of uncertainty, depression, anxiety, and stress. International Journal of Mental Health and Addiction. https://doi.org/10.1007/s11469-020-00331-y

BBC News Turkish. (2020). Koronavirüs: Türkiye'de hangi ilde, ne tür tedbirler uygulanıyor? Retrieved from: https://www.bbc.com/turkce/haberler-turkiye-52663160

Belge, J. (2019). An investigation of the relationship between depressive symptoms, anxiety symptoms and intolerance of uncertainty on a group of adults (Master's thesis). Retrieved from CoHE Thesis Center (Thesis Number: 583816).

Billett, S. (2006). Relational interdependence between social and individual agency in work and working life. Mind, Culture, and Activity, 13(1), 53-69. DOI: 10.1207/s15327884mca1301_5

Billett, S. (2008). Learning throughout working life: a relational interdependence between personal and social agency. British Journal of Educational Studies, 56(1), 39-58. DOI: 10.1111/j.14678527.2007.00394.x

Bo, H., Li, W., Yang, Y., Wang, Y., Zhang, Q., Cheung, T., Wu, X., \& Xiang, Y. (2020). Posttraumatic stress symptoms and attitude toward crisis mental health services among clinically stable patients with COVID-19 in China. Psychological Medicine as part of the Cambridge Coronavirus Collection. https://doi.org/10.1017/S0033291720000999 
Brooks, S. K., Webster, R. K., Smith, L. E., Woodland, L., Wessely, S., Greenberg, N., \& Rubin, G. J. (2020). The psychological impact of quarantine and how to reduce it: Rapid review of the evidence. The Lancet. https://doi.org/10.1016/S0140-6736(20)30460-8

Buhr, K., \& Dugas M. J. (2002). The intolerance of uncertainty scale: Psychometric properties of the English version. Behaviour Research and Therapy, 40(8), 931-45. Retrieved from https://www.sciencedirect.com/science/article/abs/pii/S0005796701000924

Cao, W., Fang, Z., Hou, G., Han, M., Xu, X., Dong, J., \& Zheng, J. (2020). The psychological impact of the COVID-19 epidemic on college students in China. Psychiatry Research, 112934. https://doi.org/10.1016/j.psychres.2020.112934

Carleton, R. N., Norton, M. A., \& Asmundson, G. J. G. (2007). Fearing the unknown: A short version of the intolerance of uncertainty scale. Journal of Anxiety Disorders, 21, 105-17. DOI: S08876185(06)00051-X [pii]10.1016/j.janxdis.2006.03.014

Chapleau, K. M., \& Oswald, D. L. (2014). A system justification view of sexual violence: Legitimizing gender inequality and reduced moral outrage are connected to greater rape myth acceptance. Journal of Trauma \& Dissociation, 15(2), 204-218. DOI: 10.1037/t48610-000

Chen, S., \& Boucher, H. C. (2008). Relational selves as self-affirmational resources. Journal of Research in Personality, 42(3), 716-733. doi:10.1016/j.jrp.2007.09.006

Coffey, D. (2020). Parisian nonchalance shattered by Macron's coronavirus address to the people. RFI. Retrieved from https://amp.rfi.fr/en/europe/20200317-parisian-nonchalance-shattered-bymacron-s-coronavirus-address-to-the-people

Crigger, N. J. (1996). Testing an uncertainty model for women with multiple sclerosis. Advanced in Nursing Science, 18(3), 37-47. DOI: 10.1097/00012272-199603000-00005

Cross, S. E., Bacon, P. L., \& Morris, M. L. (2000). The relational-interdependent self-construal and relationships. Journal of Personality and Social Psychology, 78(4), 791-808. Retrieved from https://pubmed.ncbi.nlm.nih.gov/10794381/

Cross, S. E., \& Madson, L. (1997). Models of the self: Self-construals and gender. Psychological Bulletin, 122(1), 5-37. DOI: 10.1037//0033-2909.122.1.5

Cross, S. E., Morris, M. L., \& Gore, J. S. (2002). Thinking about oneself and others: The relationalinterdependent self-construal and social cognition. Journal of Personality and Social Psychology, 82(3), 399-418. DOI: 10.1037//0022-3514.82.3.399

Cummins, E. (2020). "I'll do what I want": Why the people ignoring social distancing orders just won't listen. Vox. Retrieved from https://www.vox.com/thehighlight/2020/3/24/21191184/coronavirus-social-distancing-pandemic-spring-break-keep-calmcarry-on

Çelik Ok, M. (2019a). The effect of woman's lifestyle and gender stereotype activation on rape victim blaming and moral outrage (Doctoral dissertation). Retrieved from CoHE Thesis Center (Thesis Number: 586466). 
Çelik Ok, M. (2019b). Adaptatıon of moral outrage scale into Turkısh. Muhakeme Journal, 2(2), 19-28. DOI: $10.33817 /$ muhakeme.626140

Davidson, P. M., Padula, W. M., Daly, J., \& Jackson, D. (2020). Moral outrage in COVID19understandable but not a strategy. Journal of Clinical Nursing, 29(19-20), 3600-3602. https://doi.org/10.1111/jocn.15318

Duman, N. (2020). COVID-19 fear and intolerance to uncertainty in university students. The Journal of Social Science, 4(8), 426-437. DOI: 10.30520/tjsosci.748404

Ercan, H. (2013). A study on self construal of young adults. Journal of World of Turks, 5(2), 157-178. Retrieved from https://www.acarindex.com/dosyalar/makale/acarindex-1423939263.pdf

Gabriel, S., Renaud, J. M., \& Tippin, B. (2007). When I think of you, I feel more confident about me: The relatioanal interdependence and self-confidence. Journal of Experimental Social Psychology, 43(5), 772-779. DOI: 10.1016/j.jesp.2006.07.004

Gelfand, M. J., Major, V. S., Raver, J. L., Nishii, L. H., \& O’Brien, K. (2006). Negotiating relationally: The dynamics of relatioanal interdependence in negotiations. Academy of Management Review, 31(2), 427-451. https://doi.org/10.5465/amr.2006.20208689

Geniş, B., Gürhan, N., Koç, M., Geniş, Ç., Şirin, B., Çırakoğlu, O. C., \& Coşar, B. (2020). Development of perception and attitude scales related with COVID-19 pandemia. Pearson Journal of Social Sciences - Humanities, 5(7), 306-328. DOI: 10.46872/pj.127

Godshall, M. (2021). Coping with moral distress during COVID-19. Nursing2021, 51(2), 55-58. https://journals.lww.com/nursing/Fulltext/2021/02000/Coping_with_moral_distress_during_C OVID_19.14.aspx

Goodenough, W. (1997). Moral outrage: Territoriality in human guise. Zygon, 32(1), 5-27. https://doi.org/10.1111/0591-2385.671997067

Graupmann, V. (2020). When social exclusion is mandated: COVID-19, social distancing, gender and psychological needs. Retrieved from https://psyarxiv.com/u362n/

Grenier, S., Barrette, A. M., \& Ladouceur, R. (2005). Intolerance of uncertainty and intolerance of ambiguity: Similarities and differences. Personality and Individual Differences, 39(3), 593-600. DOI: $10.1016 /$ j.paid.2005.02.014

Güvenç, F. (2019). Relationship between cognitive flexibility and intolerance of uncertainty and personality traits university students (Master's thesis). Retrieved from CoHE Thesis Center (Thesis Number: 583636).

Hayes, A. F. (2013). Introduction to mediation, moderation, and conditional process analysis: A regression-based approach. Guilford Press.

Helweg-Larsen, M. (2020). Commentary: Partying and picnicking with friends? Your complacency this COVID-19 outbreak is misplaced. CNA International Edition. Retrieved from https://www.channelnewsasia.com/news/commentary/coronavirus-COVID-19-safe-distancingsocial-isolation-measure-us-12577568 
Hoffman, M. L. (2001). Empathy and moral development: Implications for caring and justice. Cambridge University Press.

Holaway, R. M., Heimberg, R. G., \& Coles, M. E. (2006). A comparison of intolerance of uncertainty in analogue obsessive-compulsive disorder and generalized anxiety disorder. Journal of Anxiety Disorders, 20(2), 158-174. https://doi.org/10.1016/j.janxdis.2005.01.002

İmamoğlu, E. O. (2003). Individuation and relatedness: Not: Opposing but distinct and complementary. Genetic, Social, and General Psychology Monographs, 129 (4), 367-402. Retrieved from https://avesis.metu.edu.tr/yayin/4d429131-099b-44db-b00e-75b8d616d2c2/individuation-andrelatedness-not-opposing-but-distinct-and-complementary

Jost, J. T. (2011). System justification theory as compliment, complement, and corrective to theories of social identification and social dominance. Psychology Press Taylor \& Francis Group.

Jost, J., \& Hunyady, O. (2002). The psychology of system justification and the palliative function of ideology. European Review of Social Psychology, 13(1), 111-153. https://doi.org/10.1080/10463280240000046

Kağıtçıbaşı, Ç., \& Cemalcılar, Z. (2014). Dünden bugüne insan ve insanlar: Sosyal psikolojiye giriş (16th Edition). Evrim Yayınevi.

Karasar, N. (2014). Bilimsel araştırma yöntemleri (26th Edition). Nobel Yayınevi.

Kasapoğlu, F. (2020). Examination of the relationship between anxiety with spirituality, resilience and intolerance of uncertainty in the COVID-19 outbreak process. Turkish Studies, 15(4), 599-614. https://dx.doi.org/10.7827/TurkishStudies.44284

Kugler, M. B., Cooper, J., \& Nosek, B. A. (2010). Group-based dominance and opposition to equality correspond to different psychological motives. Social Justice Research, 23(2-3), 117-155. https://doi.org/10.1007/s11211-010-0112-5

Lee, S. Y. (2010). Framing moral responsibility: The influence of moral emotions on persuasive health messages (PhD Thesis). University of Wisconsin-Madison.

Lodewijkx, H., Kersten, G., \& van Zomeren, M. (2008). Dual pathways to engage in silent marches against violence: Moral outrage, moral cleanings and modes of identification. Journal of Community and Applied Social Psychology, 18(3), 153-167. https://doi.org/10.1002/casp.916

MacKinnon, D. P., Lockwood, C. M., Hoffman, J. M., West, S. G., \& Sheets, V. (2002). A comparison of methods to test mediation and other intervening variable effects. Psychological methods, 7(1), 83. DOI: $10.1037 / 1082-989 x .7 .1 .83$

Markus, H., \& Kitayama, S. (1991). Culture and the self: Implications for cognition, emotion, and motivation. Psychological Review, 98(2), 224-253. Retrieved from https://web.stanford.edu/ hazelm/publications/1991\%20Markus\%20Kitayama\%20Culture\%20a nd\%20the\%20self.pdf

McGarty, C., \& Haslam, A. (1997). (Ed.) The Message of social psychology. Blackwell, Cambridge. 
Meng, H., Xu, Y., Dai, J., Zhang, Y., Liu, B., \& Yang, H. (2020). The psychological effect of COVID-19 on the elderly in China. Psychiatry Research, 112983. https://dx.doi.org/10.1016\%2Fj.psychres.2020.112983

Mattingly, B. a., Oswald, D. L., \& Clark, E. M. (2011). An examination of relational-interdependent selfconstrual, communal strength, and pro-relationship behaviors in friendships. Personality and Individual Differences, 50(8), 1243-1248. doi:10.1016/j.paid.2011.02.018

Mesquita, B. (2001). Emotions in collectivist and individualist contexts. Journal of Personality and Social Psychology, 80(1), 68-74. DOI: 10.1037/0022-3514.80.1.68

Montada, L. (1992). Predicting prosocial commitment in different social contexts. NYU Press.

Montada, L., \& Schneider, A. (1989). Justice and emotional reactions to the disadvantaged. Social Justice Research, 3(4), 313-344. https://doi.org/10.1007/BF01048081

Morry, M. M., \& Kito, M. (2009). Relational-interdependent self-construal as a predictor of relationship quality: The mediating roles of one's own behaviors and perceptions of the fulfillment of friendship functions. The Journal of Social Psychology, 149(3), 305-322. DOI: 10.3200/SOCP.149.3.305-322

Neys, W. D., Raoelison, M., Boissin, E., Voudouri, A., Bago, B., \& Bialek, M. (2020). Moral outrage and social distancing: bad or badly informed citizens? Retrieved from https://psyarxiv.com/j9h76/

O'Sullivan, F., \& Patino, M. (2020, March 16). Virus: Irresponsables put France on lockdown. CityLab. Retrieved from https://www.citylab.com/life/2020/03/coronavirus-france-social-mediairresponsables-COVID-19/608080/

Özdin, S., \& Bayrak Özdin, Ş. (2020). Levels and predictors of anxiety, depression and health anxiety during COVID-19 pandemic in Turkish society: The importance of gender. International Journal of Social Psychiatry, 0020764020927051. https://doi.org/10.1177\%2F0020764020927051

Özkan, Ö. S. (2019). The relationship between intolerance of uncertainty and aggression levels of obsessive compulsive disorder of individuals (Master's thesis). Retrieved from CoHE Thesis Center (Thesis Number: 599813).

Öztürk, E. B., Kılıçaslan Gökoğlu, S., \& Karagonlar, G. (2015). Validatıon of relational-interdependence scale in Turkısh context. İşletme Fakültesi Dergisi, 16(2), 49-70.

Pagano, S. J. (2007). A model of moral emotional reactions to injustice: Implications for psychological well-being and prosocial action (Doctoral dissertation). University of California, Los Angeles.

Pallant, J. (2007). SPSS kullanma kılavuzu: SPSS ile adım adım very analizi (2nd Edition). (Çev: Sibel Balcı, Berah Ahi). Anı Yayıncılık.

Parlapani, E., Holeva, V., Nikopoulou, V. A., Sereslis, K., Athanasiadou, M., Godosidis, A., Stephanou, T., \& Diakogiannis, I. (2020). Intolerance of uncertainty and loneliness in older adults during the COVID-19 pandemic. Frontiers in Psychiatry, 11(842), 1-12. DOI: 10.3389/fpsyt.2020.00842 
Pfundmair, M., Graupmann, V., Frey, D., \& Aydin, N. (2015). The different behavioral intentions of collectivists and individualists in response to social exclusion. Personality and Social Psychology Bulletin, 41(3), 363-378. https://doi.org/10.1177/0146167214566186

Preacher, K. J., \& Kelley, K. (2011). Effect size measures for mediation models: Quantitative strategies for communicating indirect effects. Psychological Methods, 16, 93-115. DOI: 10.1037/a0022658

Quasney, E. (2011). Emotional responses to gender-based inequality: Justifications and consequences (Master's thesis). Marquette University.

Ryan, F. (2020). Don't just blame the public over social distancing. Look to the government. The Guardian. Retrieved from https:/www.theguardian.com/commentisfree/2020/mar/24/socialdistancing-government-COVID-19

Rushton, C. (2013). Principled moral outrage: an antidote to moral distress. AACN Advanced Critical Care, 24(1), 82-89. https://doi.org/10.4037/NCI.0b013e31827b7746

Rushton, C. H., \& Thompson, L. (2020). Moral outrage: Promise or peril? Nurs Outlook6, 8(5), 536-538. https://doi.org/10.1016/j.outlook.2020.07.006

Saatçi, E. (2020). The effect of perfectionism, intolerance to uncertainty and psychological resilience on selfhandicapping in university students (Master's thesis). Retrieved from CoHE Thesis Center (Thesis Number: 609668).

Sarı, S., \& Dağ, İ. (2009). Problem solving style, hopelessness, helplessness and haplessness as the predictors of psychopathology assessed by MMPI-2. Anatolian Journal of Psychiatry, 10, 261-70. Retrieved from http://www.ihsandag.gen.tr/index_dosyalar/SariveDag2009.pdf

Sarıçam, H., Erguvan, F. M., Akın, A., \& Akça, M. Ş. (2014). The Turkısh short versıon of the intolerance of uncertainty (IUS-12) scale: The study of validity and reliability. Route Educational and Social Science Journal, 1(3), 148-57. Retrieved from https://toad.halileksi.net/olcek/belirsizligetahammulsuzluk-olcegi-bto-12

Scharmer, C., Martinez, K., Gorrell, S., Reilly, E. E., Donahue, J. M., \& Anderson, D. A. (2020). Eating disorder pathology and compulsive exercise during the COVID-19 public health emergency: Examining risk associated with COVID-19 anxiety and intolerance of uncertainty. International Journal of Eating Disorders, 53, 2049-2054. DOI: 10.1002/eat.23395

Sher, L. (2020). COVID-19, anxiety, sleep disturbances and suicide. Sleep Medicine. DOI: 10.1016/j.sleep.2020.04.019

Sidanius, J., \& Pratto, F. (1999). Social dominance. Cambridge University Press.

Smith, E. R., \& Mackie, D. M. (2007). Social psychology (3rd. edition) Psychology Press.

Sohrabi, C., Alsafi, Z., O'Neill, N., Khan, M., Kerwan, A., Al-Jabir, A., Losifidis, C., \& Aghad, R. (2020). World Health Organization declares global emergency: A review of the 2019 novel coronavirus (COVID-19). International Journal of Surgery, 76, 71-76. DOI: 10.1016/j.ijsu.2020.02.034.

Sun, P., Lu, X., Xu, C., Sun, W., \& Pan, B. (2020). Understanding of COVID-19 based on current evidence. Journal of Medical Virology, 92, 548-551. https://doi.org/10.1002/jmv.25722 
Sweet, L., \& Broadbent, J. (2017). Nursing students' perceptions of the qualities of a clinical facilitator that enhance learning. Nurse Education in Practice, 22, 30-36. DOI: 10.1016/j.nepr.2016.11.007

Tabachnick, B. G., \& Fidell, L. S. (2013). Using Multivariate Statistics (6th. Edition). Pearson.

Tan, X., Liu, L., Huang, Z., Zhao, X., \& Zheng, W. (2016). The dampening effect of social dominance orientation on awareness of corruption: Moral outrage as a mediator. Social Indicators Research, 125(1), 89-102. DOI: 10.1007/s11205-014-0838-9

Republic of Turkey Ministry of Health. (2020). COVID-19 (Yeni Koronavirüs Hastalı̆̆ $)$ Nedir? Retrieved from https://covid19bilgi.saglik.gov.tr/tr/COVID-19-yeni-koronavirus-hastaligi-nedir

Teo, S. S. S., \& Griffiths, G. (2020). Child protection in the time of COVID-19. Journal of Paediatrics and Child Health, 56, 838-840. https://doi.org/10.1111/jpc.14916

Thomas, E., McGarty, C., \& Mavor, K. (2009). Transforming apathy into movement: the role of prosocial emotions in motivating action for social change. Personality and Social Psychology Review, 13(4), 310-333. DOI: $10.1177 / 1088868309343290$

Triandis, H. C., \& Suh, E. M. (2002). Cultural influences on personality. Annual Review of Psychology, 53(1), 133-160. https://doi.org/10.1146/annurev.psych.53.100901.135200

Tull, M. T., Barbano, A. C., Scamaldo, K. M., Richmond, J. R., Edmonds, K. A., Rose, J. P., \& Gratz, K. L. (2020). The prospective influence of COVID-19 affective risk assessments and intolerance of uncertainty on later dimensions of health anxiety. Journal of Anxiety Disorders, 75, 1-8. https://doi.org/10.1016/j.janxdis.2020.102290

Uskul, A. K., \& Over, H. (2017). Culture, social interdependence, and ostracism. Current Directions in Psychological Science, 26(4), 371-376. https://doi.org/10.1177/0963721417699300

Wakslak, C. J., Jost, J. T., Tyler, T. R., \& Chen, E. S. (2007). Moral outrage mediates the dampening effect of system justification on support for redistributive social policies. Psychological Science, 18(3), 267-274. DOI: 10.1111/j.1467-9280.2007.01887.x

Wang, C., Pan, R., Wan, X., Tan, Y., Xu, L., Ho, C. S., \& Ho, R. C. (2020). Immediate psychological responses and associated factors during the initial stage of the 2019 coronavirus disease (COVID-19) epidemic among the general population in China. International Journal of Environmental Research and Public Health, 17(5), 1729. https://doi.org/10.3390/ijerph17051729

Wheaton, M. G., Messner, G. R., \& Marks, J. B. (2020). Intolerance of uncertainty as a factor linking obsessive-compulsive symptoms, health anxiety and concerns about the spread of the novel coronavirus (COVID-19) in the United States. Journal of Obsessive-Compulsive and Related Disorders, 28, 1-6. https://doi.org/10.1016/j.jocrd.2020.100605

Zhao, X., Lynch Jr, J. G., \& Chen, Q. (2010). Reconsidering Baron and Kenny: Myths and truths about mediation analysis. Journal of Consumer Research, 37(2), 197-206. DOI: 10.1086/651257 